\title{
Participatory Politics, Social Cooperation, and Economic Stability
}

\section{Citation}

Rodrik, Dani. 2000. "Participatory Politics, Social Cooperation, and Economic Stability." American Economic Review 90 (2): 140-44. https://doi.org/10.1257/aer.90.2.140.

\section{Permanent link}

http://nrs.harvard.edu/urn-3:HUL.InstRepos:37931537

\section{Terms of Use}

This article was downloaded from Harvard University's DASH repository, and is made available under the terms and conditions applicable to Other Posted Material, as set forth at http:// nrs.harvard.edu/urn-3:HUL.InstRepos:dash.current.terms-of-use\#LAA

\section{Share Your Story}

The Harvard community has made this article openly available.

Please share how this access benefits you. Submit a story.

\section{Accessibility}




\section{PARTICIPATORY POLITICS, SOCIAL COOPERATION, AND ECONOMIC STABILITY

\author{
Dani Rodrik
}

Few would doubt the proposition that political institutions matter for economic development. Yet we lack robust generalizations and systematic evidence on how exactly they do so. In this short paper, I draw attention to a regularity in the cross-national data that has received little attention to date: participatory political regimes are associated with significantly lower levels of aggregate economic instability. After presenting some of the evidence in the next section, I speculate that the reason has to do with the propensity of democracy to moderate social conflict and induce compromise. I discuss three distinct arguments as to why this may be the case.

\section{Some evidence}

The relationship between democracy and economic growth has been studied extensively. The data tend to show that democracy has no systematic effect on long-run growth rates. The top panel of Figure 1 shows a typical result: the partial correlation between an index of democracy during the 1970s and subsequent economic growth is virtually zero. The relationship between democracy and volatility in economic performance, on the other hand, is negative, statistically significant, and quantitatively large. This is shown in the bottom panel of Figure 1: an increase in the democracy score of 0.5 points (the difference roughly between Malaysia and the United States) is associated with a reduction in the standard deviation of annual per-capita GDP growth rates of 1.7 percentage points. ${ }^{1}$ While shortage of space precludes in-depth analysis, the latter finding seems to be a robust one. Similar results have been reported 
independently by Siddharth Chandra (1998), Dennis P. Quinn and John T. Woolley (1998), and Rodrik (1997), working with different methodologies and time periods.

What about causality? Perhaps democracy is the result of low underlying volatility, rather than vice versa. ${ }^{2}$ In principle, we could use an instrumental-variable approach to determine whether democracy is causal. Unfortunately, it is hard to think of credible instruments for democracy--i.e., variables that would predict democracy yet be uncorrelated with the error term in the volatility regression. I offer two reasons to think that causality might go from democracy to reduced instability. First, note that the index of democracy used in the empirical exercise above pertains to the beginning of the relevant period (i.e., the 1970s), and that using an index of democracy from the tail end of the period actually weakens the statistical relationship. Second, if economic instability were detrimental to democracy, we would find a negative and significant correlation between an exogenous measure of instability such as terms-of-trade volatility and the democracy index. In reality, the relationship is negative but very far from statistical significance (results are available upon request). The tentative conclusion is that political democracy does enhance economic stability.

This finding is important since instability in economic performance has been one of the defining features of the growth experience in the developing world (William Easterly at al., 1993; Lant Pritchett, 1997). It is also important because economic volatility is a source of potentially large welfare losses in a world with incomplete insurance markets and inadequate levels of intertemporal trade.

\section{Three perspectives on social cooperation}

One way to interpret the result is that democracies produce policy stability because of the constraints generated by the separation of powers, the rule of law, and other restrictions on the 
use of executive power. However, the simple view that democracy generates paralysis and status quo bias in policy-making due to the presence of multiple veto points is belied by the evidence that democracies are actually better at adjusting policies in response to shocks (see Rodrik, 1999). I pursue a different avenue here, arguing that democracies induce greater willingness to cooperate and compromise in the political sphere, generating greater stability as a result.

\section{A. Cooperation induced by deliberation}

One way in which democratic participation in politics can generate compromise is by altering preferences. As individuals meet and deliberate, they come to understand each other's viewpoints, develop empathy, recognize the value of moderation, internalize the common interest, and de-emphasize narrow self-interest. This is an old theme in democratic theory. One of the merits of democratic participation, wrote John Stuart Mill (1946 [1861], 150), is that the citizen

is called upon, while so engaged, to weigh interests not his own; to be guided, in case of conflicting claims, by another rule than his private partialities; to apply, at every turn, principles and maxims which have for their reason of existence the common good.... He is made to feel himself one of the public, and whatever is for their benefit to be for his benefit.

In this view, democracy induces cooperation and compromise not by changing the constraints we face, but by changing the type of people we are. Democracy makes us less selfish and more public spirited.

\section{B. Cooperation induced by restrictions on feasible redistributions}

Liberal democracies entail constitutional rules that curtail the power of the majority to expropriate the minority. Separation of powers, specific minority protection clauses, and the rule of law are some of the more relevant mechanisms. Reducing the scope of redistributive action induces cooperative behavior through two channels. First, winners cannot treat the losers as they 
please. Second, and less obviously, this fact in itself makes contending groups more willing to compromise ex ante, as it reduces both the perceived benefits of uncooperative behavior and the perceived costs of cooperative behavior.

Consider a situation where a policy adjustment needs to take place in response to an adverse external shock. There are two groups in the model and each group must decide what share of a shrinking pie it will claim. If the claims exceed the available resources, the resulting social conflict generates deadweight losses, and the size of the pie shrinks further. The ex post distribution of resources is determined partly by the ex ante claims, and partly by constitutional rules that restrict the range of feasible redistributions.

Normalize the pre-existing level of resources in the economy to unity, and assume that these resources were initially split evenly between the two groups. The external shock is of magnitude $\Delta$, and reduces the economy's resources to $1-\Delta$. Each group must decide between one of two strategies. The "cooperative" strategy consists of scaling down the group's demand in proportion to the lost income; that is, to claim only $1 / 2(1-\Delta)$. Alternatively, each group can choose to "fight" by holding onto its previous stake of $1 / 2$.

Unless both groups decide to behave cooperatively, the costs of the shock are magnified. These added costs come in two parts. First, there is a fixed cost $(\tau)$ arising from the onset of social conflict, and second, there is a loss that is proportional to the excess demand for resources. Hence, denoting the demand made by group $i$ as $\alpha_{i}$, the resources that are available for distribution to the two groups are:

(1) $R=\left\{\begin{array}{l}(1-\Delta)-\theta\left[\sum \alpha_{i}-(1-\Delta)\right]-\tau, \text { if either group fights } \\ (1-\Delta), \text { otherwise. }\end{array}\right.$ Here, $\theta$ captures the sensitivity of the economy's performance to excess demands ex ante. 
The available resources $R$ are eventually distributed according to the following rules. If both groups opt for the same strategy, $R$ is split evenly between them: when they both cooperate, they each get $1 / 2 R_{c c} \equiv \frac{1}{2}(1-\Delta)$, and when they both fight, they each get $1 / 2 R_{f f} \equiv 1 / 2\{(1-\Delta)-\theta \Delta-\tau\}$. When the choices are asymmetric, constitutional rules help determine the outcome. In the absence of any restrictions on redistribution, an opportunistic group that chooses to fight while the other group cooperates can shut out the latter from the distributive process and capture its full claim, $1 / 2$. In this case, the cooperating group is left with the residual $R_{c f}-1 / 2 \equiv\left\{(1-\Delta)-\theta \frac{\Delta}{2}-\tau\right\}-1 / 2$. At the other extreme, we can imagine that constitutional restrictions prohibit asymmetric gains, in which case the available resources $R_{c f}=\left\{(1-\Delta)-\theta \frac{\Delta}{2}-\tau\right\}$ are divided evenly between the two groups. We assume that the actual outcome is a weighted average of these two extremes, with the weight on the second scenario, $\phi$, serving to calibrate the extent of constitutional restrictions on redistribution.

Let $\pi$ stand for the probability that each group attaches to the other's non-cooperative behavior. The expected value of cooperation, $E V_{c}$, from the perspective of each group can be expressed as:

$$
E V_{c}=[1 / 2 \phi+(1-\phi)] \pi R_{c f}+1 / 2(1-\pi) R_{c c}-1 / 2 \pi(1-\phi)
$$

The expected value of fighting, $E V_{f}$, is:

$$
E V_{f}=1 / 2\left\{\pi R_{f f}+(1-\pi)\left[(1-\phi)+\phi R_{c f}\right]\right\}
$$

The optimal strategy depends on which of these is larger. I focus on symmetric cases where the two groups are identical in all respects, including their strategies in equilibrium.

Restricting ourselves to pure strategies - a group either cooperates with probability one or fights with probability one-we can look for fulfilled-expectations equilibria in which $\pi$ is 
either one or zero. The nature of the equilibrium depends on the underlying parameters. In particular, with $\phi$ sufficiently high (i.e., with constitutional strictures against redistribution sufficiently strong), the unique equilibrium is $\pi=0$. Intuitively, restrictions on feasible redistribution eliminate the incentive not to compromise because they reduce the potential return to fighting and the potential cost of cooperating. If $\phi$ is sufficiently low, on the other hand, the unique equilibrium is $\pi=1$ and both groups choose to fight. For intermediate values of $\phi$, there are multiple equilibria in which beliefs of either kind about the other group's action can be selffulfilling.

\section{Cooperation induced by repeated interaction among political groups}

As Avinash Dixit, Gene M. Grossman, and Faruk Gül (forthcoming) have noted, democratic regimes produce compromise even when there are no explicit constitutional rules that moderate behavior. (They cite the U.K. as an example.) They show that repeated interaction between political groups can generate compromise, as long as the group that happens to be in power at any point in time (a) knows that it will not remain in power forever, and (b) is sufficiently likely to return to power once displaced. The incentive to compromise is sustained thanks to a trigger strategy equilibrium in which the group in power trades off the short run costs of not adopting its most preferred policy against the long-run benefits of inducing cooperative behavior on the part of its rival.

I follow the simplified exposition in Dixit (1999) with some minor changes. Let two groups, $A$ and $B$, have instantaneous utility functions $u_{A}(x)$ and $u_{B}(x)$, where $x$ denotes the choice over some policy. Let the two groups' most preferred policies be $x_{A}$ and $x_{B}$, respectively. Let $p$ stand for the probability that a group in power this period will remain in power the next period. Consider first an equilibrium in which a group in power refuses to compromise and follows its 
most preferred policy. Denote by $V_{A}^{p}$ and $V_{A}^{n p}$ the discounted expected utilities of group A under this equilibrium when it is in and out of power, respectively. These can be written in the following recursive form (Dixit 1999):

$$
\begin{aligned}
& V_{A}^{p}=u_{A}\left(x_{A}\right)+\delta\left[p V_{A}^{p}+(1-p) V_{A}^{n p}\right] \\
& V_{A}^{n p}=u_{A}\left(x_{B}\right)+\delta\left[p V_{A}^{n p}+(1-p) V_{A}^{p}\right],
\end{aligned}
$$

where $\delta$ is the discount factor. Solving these two equations yields expressions for $V_{A}^{p}$ and $V_{A}^{n p}$ in terms of the underlying parameters of the model.

Let the compromise policy be the mid-point between $x_{A}$ and $x_{B}, \bar{x} \equiv\left(x_{A}+x_{B}\right) / 2$. When both groups compromise, the discounted utility of group $\mathrm{A}$ is $V_{A}^{*}=u_{A}(\bar{x}) /(1-\delta)$. Assume that a group reverts forever to its no-compromise strategy when the other group "defects" from the compromise policy. When will compromise be an equilibrium strategy for the groups in power? Looking at the question from $A$ 's perspective, compromise makes sense as long as it yields a discounted stream of future benefits that is higher than would be obtained under the most preferred policy in the short run, i.e., as long as $V_{A}^{*} \geq V_{A}^{p}$. Using (4) and (5), this condition can be expressed as

$$
\frac{\delta(1-p)}{1-\delta p} \geq \frac{u_{A}\left(x_{A}\right)-u_{A}(\bar{x})}{u_{A}(\bar{x})-u_{A}\left(x_{B}\right)}
$$

as in Dixit (1999).

Three points are noteworthy about this result. First, there must be a high enough probability of switches in power between two groups for compromise to be an equilibrium outcome. In the limit, when a group perceives that it can remain in power almost forever ( $p \approx 1$ ), it will have no incentive to moderate its policies. Second, the more risk-averse are the groups (as captured by the concavity of the instantaneous utility function), the more likely is it 
that compromise will result. Finally, as long as the groups are risk averse, a larger difference in the preferred policies of the two groups (in the sense of a mean-preserving spread between $x_{A}$ and $x_{B}$ ) is more likely to produce compromise. The last result implies that heterogeneity in preferences (generated for example by ethnic or regional differences) is more--rather than less-conducive to compromise under a democratic system with frequent enough changes in the identity of office holders.

In a stable autocracy, the ruler expects to remain in office for a long time, implying that $p$ is very large and close to unity. In this case, compromise is less likely. Even though power switches hands infrequently, there is less policy stability than in a democracy. Alternatively, we could imagine an unstable autocracy where power changes hands frequently, but in which a ruler has no chance of coming back once he is displaced. ${ }^{3}$ In this case too, cooperation cannot be sustained by trigger strategies since today's ruler gains nothing by accommodating the preferences of yesterday's ruler. In both instances, autocracies generate greater policy instability, and the instability is increasing in the heterogeneity of preferences within society.

\section{Concluding remarks}

It is sometimes said that democracy is a luxury that poor, divided societies cannot afford. All three perspectives outlined above suggest, to the contrary, that democracy is of economic value precisely in societies where ethnic, linguistic, geographical, and other cleavages would otherwise result in excessive amounts of socially unproductive opportunistic behavior. Along with the empirical results discussed previously, this is good news for the increasing number of developing countries that are moving in the direction of participatory governance. 


\section{REFERENCES}

Acemoglu, Daron, and James A. Robinson. "A Theory of Political Transitions." Mimeo, MIT and University of California at Berkeley, July 1999.

Chandra, Siddharth. “On Pillars of Democracy and Economic Growth.” Mimeo, Graduate School of Public and International Affairs, University of Pittsburgh, February 1998.

Dixit, Avinash. "Some Lessons from Transaction-Cost Politics for Less-Developed Countries." Mimeo, Princeton University, August 1999.

; Grossman, Gene M. and Gül, Faruk. "A Theory of Political Compromise."

Journal of Political Economy, 2000, forthcoming.

Easterly, William; Kremer, Michael; Pritchett, Lant and Summers, Larry. "Good Policy or Good Luck? Country Growth Performance and Temporary Shocks,” Journal of Monetary Economics, 1993, 32, pp. 459-483.

Mill, John Stuart. On Liberty and Considerations of Representative Government. Oxford: Basil Blackwell, 1946[1861].

Pritchett, Lant. "Economic Growth: Hills, Plains, Mountains, Plateaus and Cliffs.” Mimeo, World Bank, October 1997.

Quinn, Dennis P., and Woolley, John T. "Democracy and National Economic Performance: The Search for Stability.” Mimeo, School of Business, Georgetown University, June 1998.

Rodrik, Dani. "Democracy and Economic Performance." Mimeo, John F. Kennedy School of Government, Harvard University, December 1997.

. "Where Did All the Growth Go? External Shocks, Social Conflict, and Growth Collapses," Journal of Economic Growth, December 1999, 4(4), pp. 385-412. 

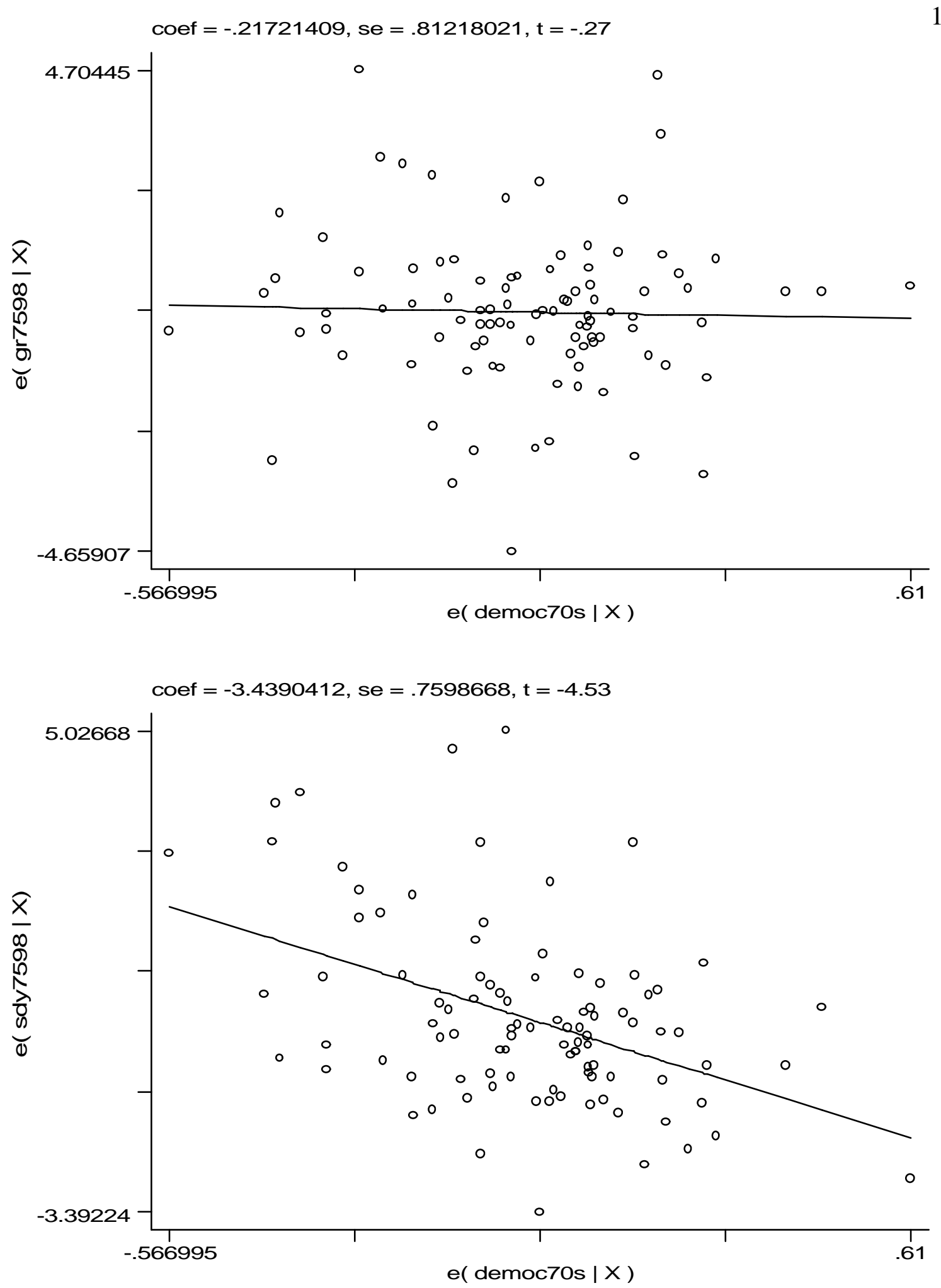

FIGURE 1. THE PARTIAL CORRELATION BETWEEN DEMOCRACY AND (A) GROWTH OF PER-CAPITA GDP (TOP PANEL); AND (B) STANDARD DEVIATION OF ANNUAL GROWTH RATES IN PER-CAPITA GDP (BOTTOM PANEL) 
FOOTNOTES

* John F. Kennedy School of Government, Harvard University, Cambridge, MA 02138 (dani_rodrik@harvard.edu). I am grateful to Daron Acemoglu and Avinash Dixit for very useful comments.

${ }^{1}$ The index of democracy is an average of the Freedom House indices of civil liberties and political rights, averaged for the 1970s and rescaled to [0-1]. Growth and its volatility are measured over the period 1975-1998 (with shorter time spans for some countries with fewer data points). The following controls are used in both regressions: log per-capita GDP in 1975, log population, a measure of terms of trade volatility, and dummies for Latin America, East Asia, Sub-Saharan Africa, and oil exporters. The sample covers 96 countries.

${ }^{2}$ See Acemoglu and Robinson (1999) for a model with two-way interaction between democracy and volatility.

${ }^{3}$ We obviously have to complicate the model now to admit more than two rulers. 